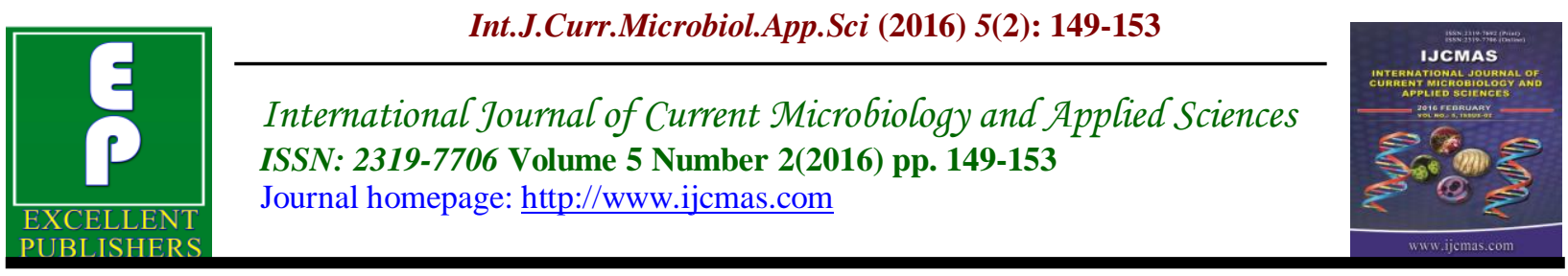

Original Research Article doi: http://dx.doi.org/10.20546/ijcmas.2016.502.017

\title{
Poly Acrylamide Gel Electrophoretic Studies on Ampelopteris prolifera, Ophioglossum petiolatum and Marsilea minuta
}

\section{S.Dominic Rajkumar ${ }^{1 *}$, M.Johnson ${ }^{2} *$, T. Shibila ${ }^{2}$, Shashank Kumar Singh ${ }^{1}$, Shobhit Kumar Srivastava ${ }^{1}$ and Ravi Pratap Gautam ${ }^{1}$}

\author{
${ }^{1}$ Department of Botany, St. Andrew's College, Gorakhpur- 273001, Uttar Pradesh, India \\ ${ }^{2}$ Centre for Plant Biotechnology, Department of Botany, St. Xavier's College (Autonomous), \\ Palayamkottai, Tamil Nadu, India \\ *Corresponding author
}

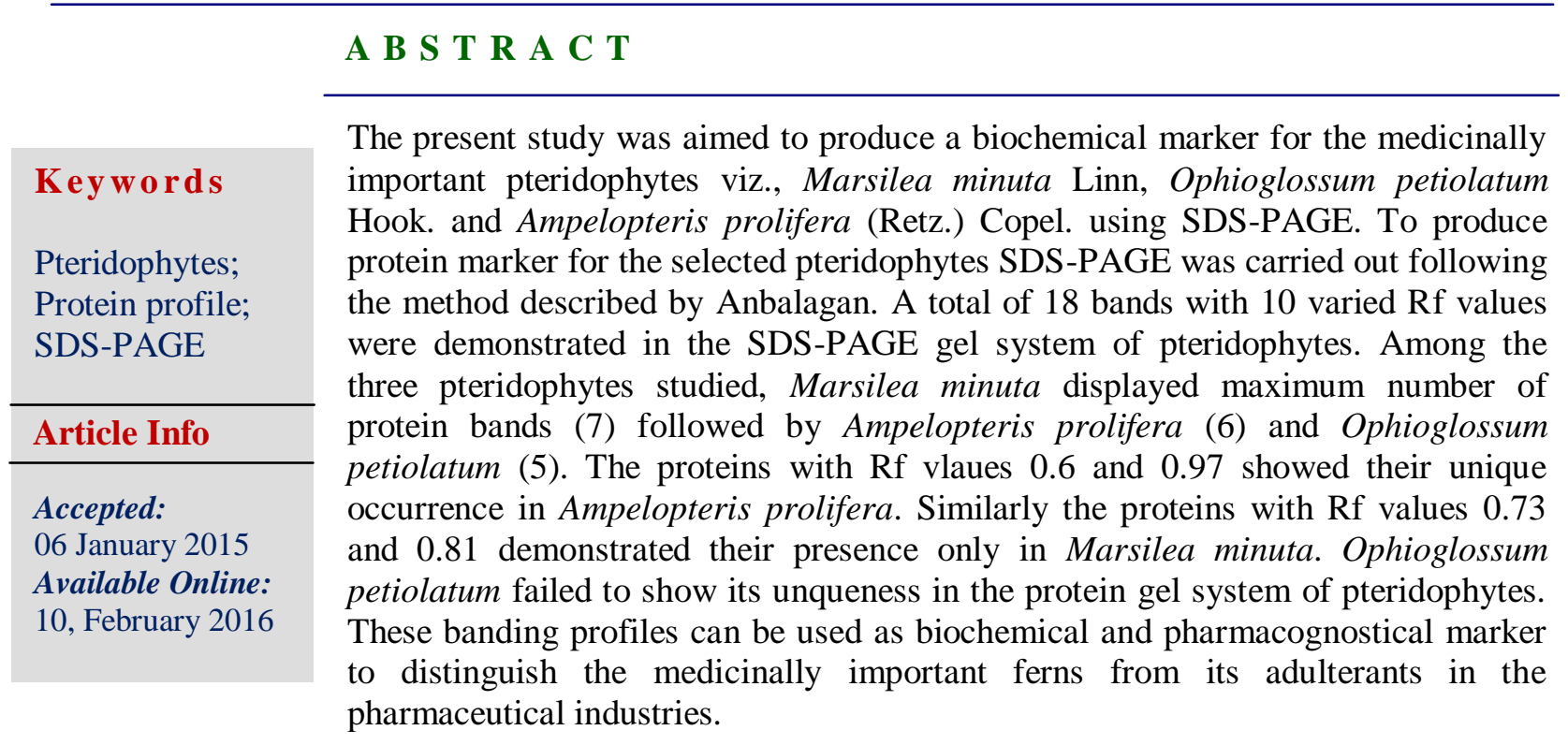

\section{Introduction}

Marsilea minuta Linn (Marsileaceae) is usually found near the ponds edges and channels and as a weed in wet rice field (Parrotta, 2001). The pharmacological and biological studies on Marsilea minuta clearly indicated the various medicinal values of an aquatic fern viz., anti-infertility (Bhardwaja and Garg, 1984), antibacterial (Parihar et al., 2003), anxiolytic (Bhattamisra et al., 2007), anticonvulsant and sedative (Chatterjee et al., 1963), analgesic and anti-inflammatory (Bhattamisra et al., 2009), antidepressant (Bhattamisra et al., 2008), adaptogenic and antistress activity (Tiwari et al., 2009), hypocholesterolemic (Gupta et al., 2000) and hepatoprotective (Praneetha et al., 2011) activities. Shirolkar et al., (2014) studied the interspecific and intra specific variation between the Marsilea minuta Linn. and Marsilea quadrifolia Linn. using RAPD markers. Madhu et al., (2014) studied the 
pharmacognostical characters of Marsilea minuta Linn. Revathi and Cathrin Sara (2014) studied the phytochemical composition of Marsilea minuta. Thick paste of Ophioglossum petiolatum from fresh rhizomes and tubers were effective against hair fall. Lin et al. (2005) isolated homoflavonoids from Ophioglossum petiolatum. Shankar and Khare (1985) studied the phytochemical composition of Ampelopteris prolifera (Retz.) Copel. Mandal and Mondal (2012) studied the aminoacid profile of $A$. prolifera. Semwal et al., (2013) evaluated the antioxidant properties of $A$. prolifera. Bharti and Pravesh (2012) studied the antibacterial potentials of Ampelopteris prolifera. But there is no report on the biochemical markers for Ampelopteris prolifera, Ophioglossum petiolatum and Marsilea minuta. Among the various analytical tools, electrophoresis is a relatively simple, rapid and highly sensitive tool to study the properties of proteins and nucleic acids. SDS-PAGE has often been employed to know the biochemical variation, inter and intra specific variation and evolutionary relationships among the plant species (Johnson et al., 2005; Johnson, 2007; Sivaraman et al., 2011; Revathy et al., 2011; Narayani and Johnson, 2013 and Johnson, 2015). With this knowledge the present study was aimed to produce a biochemical marker for the medicinally important pteridophytes using SDS-PAGE.

\section{Materials and Methods}

For the electrophoresis studies, $500 \mathrm{mg}$ young individual croziers (Young sporophytes) of Ampelopteris prolifera (Retz.)Copel (SAC - 327), Ophioglossum petiolatum (SAC - 307) and Marsilea minuta L (SAC - 315) were harvested from the natural habitat and established in the Botanic Garden of Department of Botany,
St. Andrew's College, Gorakhpur- 273001, Uttar Pradesh, India. The croziers were ground on ice cold mortar and pestle with $0.1 \mathrm{M}$ Tris buffer ( $\mathrm{pH} 7.0)$. The resultant slurry was centrifuged at $10,000 \mathrm{rpm}$ for 10 min at $4^{\circ} \mathrm{C}$ in cooling centrifuge and the supernatant was stored at $-70^{\circ} \mathrm{C}$ before use. SDS-PAGE was carried out to obtained protein bands with $6 \%$ stacking and $10 \%$ separating gel (Anbalagan, 1999). After electrophoresis the gel was observed using a Vilber Loubermat gel documentation system and banding profiles of protein was compared by zymogram. After electrophoresis the gel was observed using a Vilber Loubermat gel documentation system and banding profiles of protein was compared by zymogram.

\section{Results and Discussion}

The relative positions of the protein bands of the studied ferns viz., Ampelopteris prolifera, Ophioglossum petiolatum and Marsilea minuta were collected from natural habitat of Gorakhpur India were revealed by SDS-PAGE. Multiple regions (5) of activity were observed from protein electrophoretic system of pteridophytes. A total of 18 bands with 10 varied $R f$ values were demonstrated in the SDS-PAGE gel system of pteridophytes (Table 1; Fig. 1). Among the three pteridophytes studied, Marsilea minuta displayed maximum number of protein bands (7) followed by Ampelopteris prolifera (6) and Ophioglossum petiolatum (5). The observed protein profile clearly demonstrated the simialrity and variation among the pteridophytes and confirmed the role of protein profile in similarity and variation among the studied pteridophytes. Each region expressed different proteins which act as representative of the expression of a particular gene in the studied pteridophytes. 
Table.1 Protein Profile of Ampelopteris prolifera, Ophioglossum petiolatum and Marsilea minuta

\begin{tabular}{|r|l|l|l|l|}
\hline MW-Rf & Positions & $\begin{array}{l}\text { Ophioglossum } \\
\text { petiolatum }\end{array}$ & $\begin{array}{l}\text { Marsilea } \\
\text { minuta }\end{array}$ & $\begin{array}{l}\text { Ampelopteris } \\
\text { prolifera }\end{array}$ \\
\hline 0.56 & $\mathrm{PP6}^{1}$ & $*$ & $*$ & \\
\hline 0.6 & $\mathrm{PP6}^{2}$ & & & $*$ \\
\hline 0.65 & $\mathrm{PP7}^{1}$ & $*$ & $*$ & \\
\hline 0.69 & $\mathrm{PP7}^{2}$ & $*$ & $*$ & $*$ \\
\hline 0.73 & $\mathrm{PP}^{1}$ & & $*$ & \\
\hline 0.79 & $\mathrm{PP}^{2}$ & $*$ & & $*$ \\
\hline 0.81 & $\mathrm{PP}^{1}$ & & $*$ & \\
\hline 0.87 & $\mathrm{PP}^{2}$ & & $*$ & $*$ \\
\hline 0.9 & $\mathrm{PP}^{1} 0^{1}$ & $*$ & $*$ & $*$ \\
\hline 0.97 & $\mathrm{PP}^{2} 0^{2}$ & & & $*$ \\
\hline & & & & \\
\hline
\end{tabular}

Fig.1 SDS - PAGE Profile and Zymogram of Adiantum from Gorakhpur A: 1 - Ampelopteris Prolifera; 2 - Marsilea Minuta; 3 - Ophioglossum Petiolatum B: 1- Ophioglossum Petiolatum; 2 - Marsilea Minuta; 3 - Ampelopteris Prolifera

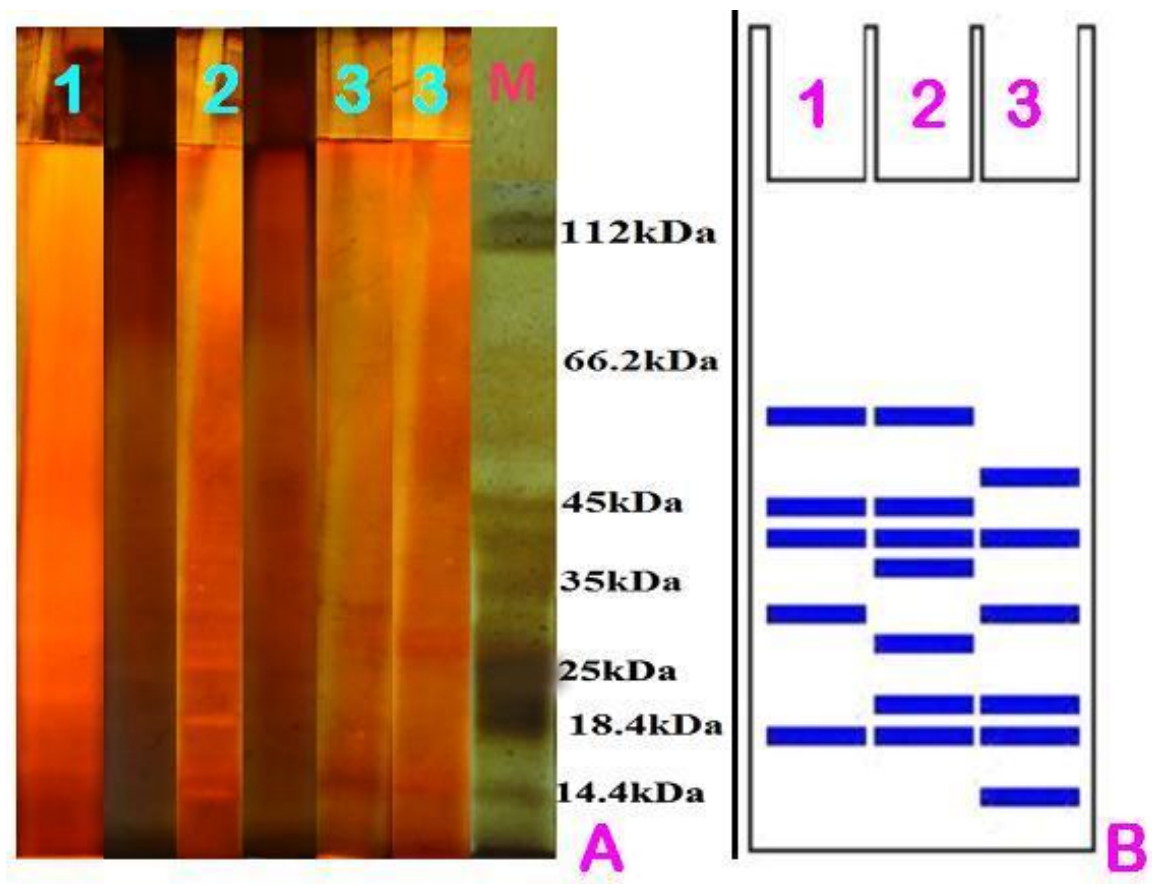

Based on the occurrence of proteins in the pteridophytes gel system, the protein profiles were classified into ten regions. The first five regions have failed to show the presence of proteins in the gel system of pteridophytes. The proteins with $\mathrm{Rf}$ vlaues
0.6 and 0.97 showed their unique occurrence in Ampelopteris prolifera. Similarly the proteins with $\mathrm{Rf}$ values 0.73 and 0.81 demonstrated their presence only in Marsilea minuta. The Ophioglossum petiolatum failed to show its unqueness in 
the protein gel system of pteridophytes. The protein with $\mathrm{Rf}$ value 0.69 and 0.9 showed their common existence in all the three studied pteridophytes. The proteins with $\mathrm{Rf}$ value 0.56 and 0.65 illustrated their jointly presence in the terestrial fern Ophioglossum petiolatum and aquatic fern Marsilea minuta. The protein with $\mathrm{Rf}$ value 00.87 dispalyed its occurrence in aquatic fern Marsilea minuta and terestrial fern Ampelopteris prolifera. The protein with $\mathrm{Rf}$ value 0.79 showed its common existence in terestrial ferns Ophioglossum petiolatum and Ampelopteris prolifera. Similarly Johnson et al., (2005), Johnson (2007), Sivaraman et al. (2011), Revathy et al. (2011), Narayani and Johnson (2013) and Johnson (2015) used the protein profiles as a tool to distinguish the ferns. The results of the present study directly supplemented with the previous observation. These banding profiles can be used as biochemical and pharmacognostical marker to distinguish the medicinally important ferns from its adulterants in the pharmaceutical industries.

\section{Acknowledgement}

The authors are thankful to the Principal, St. Andrew's college (PG), Gorakhpur, Uttar Pradesh and the Principal, St. Xavier's College, Palayamkottai, Tamil Nadu for the facilities and the encouragement given to us. One of the authors (SDR) is thankful to DBT, New Delhi (BT/HRD/02/017/2013 28.07.2014) for the financial assistance through STTP.

\section{References}

Anbalagan K (1999) An introduction to electrophoresis, Electrophoresis Institute Yercaud, Tamil Nadu, India, pp. 105.

Bhardwaja TN, Garg A. The antifertility effect of an Australian species of the aquatic fern Marsilea L. Indian Fern J. 1984; 1: 75-82.

Bharti $M$ and Pravesh R. Antibacterial activity of Lygodium flexuosum (L.) Sw. and Ampelopteris prolifera (Retz.)Copel of Ranchi District of Jharkhand The Ecoscan 2012; 1: 397- 401.

Bhattamisra SK, Khanna VK, Agrawal AK, Singh PN, Singh SK. Anti-depressant activity of standardized extract of Marsilea minuta Linn. J. Ethno Pharmacol. 2008; 117: 5157.

Bhattamisra SK, Singh PN, Singh SK, Kumar V. Anxiolytic activity of Marsilea minuta Linn. in rodents. Journal of Herbal Medicine and Toxicol. 2007; 1: 15-20.

Bhattamisra SK, Singh PN, Singh SK. Antiinflammatory and analgesic activity of ethanolic extract of Marsilea minuta Linn in rodents. Drug lines. 2009. In press.

Chatterjee A, Dutta CP, Chaudhury B, Dey PK, Dey CD, Chatterjee C, Mukherjee SR. The chemistry and pharmacology of Marceline: a sedative and anticonvulsant principle isolated from Marsilea minuta Linn. and Marsilea rajastanensis Gupta. J. Experimental Medical Sci. 1963; 7: 53-67.

Gupta RS, Kumar P, Sharma A, Bhardwaja TN, Dixit VP. Hypocholesterolemic activity of Marsilea minuta Linn. in gerbils. Fitoterapia. 2000; 71:113-117.

Johnson M, Berhanu A, Mulugeta K, Eyayu M, Manickam VS (2005) Regeneration from callus cultures of Rhinacanthus nasutus L. Kurtz. Eth J Sci Tech. 3: 17-24.

Johnson M, Irudayaraj V, Rajkumar SD, Manickam VS. Isozyme Markers for the Crude Drugs of Maiden Hair Ferns from the Western Ghats, South India. Natural products: An Indian J 2010; 6(1):55.

Johnson M. (2007) Somoclonal variation studies on Phyllanthus amarus Schum \& Thonn. Iranian Journal of Biotechnology 5(4): 240-245.

Lin YL, Shen CC, Huang YJ, and Chang YY. Homoflavonoids from Ophioglossum petiolatum J. Nat. Prod., 2005, 68 (3): 381-38

Madhu S, Kannabiran V, Murugesan S, Charli M, Nithyaa K. Pharamcognostical studies on leaves of Marsilea minuta Linn Int Res. J Pharm. 2014; 5 (3): 215-219. 
Mandal A, Mondal AK. Qualitative analysis of free amino acids of some Pteridophytes with special reference to their Ethnomedicinal uses in West Bengal, India IJSN, 2012; 3(4): 819-823.

Manickam VS, Irudayaraj V. Pteridophyte flora of the Western Ghats- South India. New Delhi: BI Publications; 1992.

Narayani M, Johnson M (2013) Inter specific proteomic studies on selected Selaginella species using SDS-PAGE. Journal of Basic and Applied Biology 7(1): 317- 328.

Nei M, Li WH (1979) Mathematical model for studying genetic variation in terms of restriction endonucleases. Proc. Natl. Acad. Sci. 76: 5269-5273.

Parihar P, Daswani L, Bohra A. Toxic effect of plant of Marsilea minuta L. on the growth of Staphylococcus aureus. Indian Fern J. 2003; 20: 48-50.

Parrotta JA. Healing ants of peninsular India. CAB International Publishing, New York. 2001. 24-25.

Praneetha P, Swaroopa Rani V, Ravi Kumar B. Hepatoprotective activity of methanolic extract of leaves of Marsilea minuta Linn against $\mathrm{CCl} 4$ induced hepatic damage in rats. Global Journal of Pharmacology. 2011; 5 (3): 164-171.

Revathi M, Catharin Sara S. Phytochemical Studies on Leaves and Petiole extracts of Marsilea minuta,L. International Journal of Science and Research 2014; 3(5): 1872 $-1874$.

Revathy I, Johnson M, Babu A, Janakiraman N, Paralogaraj A, Irudayaraj V (2011) In vivo developmental ontogeny and protein expression studies on the selected ferns from the Western Ghats, South India. Journal of Basic and Applied Biology 5(3 \& 4): 194-205.

Semwal A, Farswan MS, Upreti K, Bhatt SP, Upadhyaya K. Evaluation of Antioxidant Activity of Some Pteridophytes International Journal of Herbal Medicine 2013; 1(1): 2-5.

Shankar R and Khare PK 1985 Phytochemical studies on Ampelopteris prolifera (Retz.) Copel and Diplazium esculentum Sw. J Econ. Tax. Bot. 6: 499 - 502.

Shirolkar AR, Wadurkar S, Rao G, Murthy S $\mathrm{N}$, Pawar SD. Intra-Species comparison of Marsilea minuta Linn. and Marsilea quadrifolia Linn. Using RAPD Markers to analyze the genetic variations Int $\mathbf{J}$ Pharm Pharm Sci, 2014; 6 (2): 78-80.

Singh M, Singh N, Khare P.B., Rawat A.K.S. Antimicrobial activity of some important Adiantum species used traditionally in indigenous systems of medicine Journal of Ethnopharmacology 115 (2): 327-329.

Sivaraman A, Johnson M, Babu A, Janakiraman N, Paralogaraj A, Renisheya Joy Jeba Malar T, Narayani M (2011) Morphogenetic development and protein expression studies on selected ferns from Western Ghats, South India. Journal of Basic and Applied Biology 5(3 \& 4): 206219.

Tiwari OP, Bhattamisra SK, Singh PK, Singh SK, Kumar V. Adaptogenic antistress activity of Standardized extract of Marsilea minuta Linn. Pharmacology Online. 2009; 1: 290-299.

\section{How to cite this article:}

Dominic Rajkumar, S., M.Johnson, T. Shibila, Shashank Kumar Singh, Shobhit $\quad$ Kumar Srivastava and Ravi Pratap Gautam. 2016. Poly Acrylamide Gel Electrophoretic Studies on Ampelopteris prolifera, Ophioglossum petiolatum and Marsilea minuta. Int.J.Curr.Microbiol.App.Sci. 5(2): 149-153. doi: $\underline{\text { http://dx.doi.org/10.20546/ijcmas.2016.502.017 }}$ 